\title{
Truth and Reparation for the U.S. Imprisonment and Policing Regime
}

\section{A Transitional Justice Perspective}

\author{
Jennifer M. Page ${ }^{1 *}$ and Desmond King ${ }^{2}$ \\ ${ }^{1}$ Center for Ethics, University of Zurich, Zurich, Switzerland \\ ${ }^{2}$ Department of Politics and International Relations, University of Oxford, Oxford, UK \\ *Corresponding author. Email: jennifer.page@uzh.ch
}

\begin{abstract}
In the literature on transitional justice, there is disagreement about whether countries like the United States can be characterized as transitional societies. Though it is widely recognized that transitional justice mechanisms such as truth commissions and reparations can be used by Global North nations to address racial injustice, some consider societies to be transitional only when they are undergoing a formal democratic regime change. We conceptualize the political situation of low-income Black communities under the U.S. imprisonment and policing regime in terms of three criteria for identifying transitional contexts: normalized collective and political wrongdoing, pervasive structural inequality, and the failure of the rule of law. That these criteria are met, however, does not necessarily mean that a transition is taking place. Drawing on the American political development and abolition democracy literatures, we discuss what it would mean for the United States to transition out of its present imprisonment and policing regime. A transitional justice perspective shows the importance of not only pushing for truth and reparation, but for an actual transition.
\end{abstract}

Keywords: Transitional Justice; Reparations; Policing; Mass Incarceration; Abolitionism; Democracy

\section{Introduction}

Transitional justice is a way for societies to come to terms with injustice and violence, particularly in the context of a formal democratic regime change. Truth commissions and reparations are among transitional justice's various mechanisms and aim to provide accountability for past abuses and to lay the groundwork for democratic rule to supplant the rule of force.

Within the transitional justice literature, it is contentious as to how to conceptualize injustice and violence in the context of Global North nations like the United States. Black Americans, particularly those who live in segregated, low-income communities, are subject disproportionately to police violence, overpunishment, and a wide range of structural inequalities. Is the United States a transitional context? There is little doubt that the mechanisms of transitional justice can be used in societies that are not undergoing a formal regime change. Truth commissions and reparations programs have taken place in countries

(C) The Author(s), 2021. Published by Cambridge University Press on behalf of Hutchins Center for African and African American Research. This is an Open Access article, distributed under the terms of the Creative Commons Attribution licence (http:// creativecommons.org/licenses/by/4.0/), which permits unrestricted re-use, distribution, and reproduction in any medium, provided the original work is properly cited. 
like the United States, Canada, and Australia to address legacies of historical injustices (Ladisch and Roccatello, 2021). However, as Rosemary Nagy (2008) writes, "it is also rather awkward to affix the label 'transitional' to justice long denied in liberal democracies. To say that the transition to democracy is as yet incomplete or that we are transitioning to a reconciled, more just society, may overly broaden notions of democratisation or transition" (p. 281). There is, in other words, a potential misnomer in describing anti-Black institutional racism in the United States as a transitional context. What is specifically transitional about this context-namely, an in-progress regime change-is arguably lost in such a description.

This article analyzes imprisonment and policing-based state violence against Black Americans using a transitional justice framework. Drawing on Colleen Murphy's (2017) recent conceptual work, we discuss the political situation of low-income Black communities in terms of three categories for identifying transitional contexts: normalized collective and political wrongdoing, pervasive structural inequality, and the failure of the rule of law. But, we argue, there are also respects in which the United States departs from paradigmatic transitional contexts. An important insight about the meaning of transitional justice in the Global North follows. An ever-present hazard is the exclusive focus on transitional justice's mechanisms and a reckoning with history while failing to acknowledge when present circumstances warrant a full-blown regime change. ("Regimes" can be understood not only as the formal structures of governance, but also as political orders.) The mechanisms of truth and reparation are essential for accountability; but unless we conceptualize the United States as in need of a transition, there is only so much these mechanisms would accomplish. A transitional justice perspective, then, shows that there needs to be what contemporary abolitionists have long recognized: a complete transformation in the existing way of policing and punishing Black people in the United States. This, paired with truth and reparation, would be transitional justice.

In addition to making this argument our analysis has two further aims. First, it advances the debate on the applicability of transitional justice theory to the Global North, working out the commonalities between the U.S. and paradigmatic transitional contexts and discussing what it means for Global North countries to undergo a transition. In particular, we argue for the relevance of "abolition democracy" to conceptualizing regime change in the context of the United States. This concept originated in the thought of W. E. B. Du Bois ([1935]1998) and is taken up by Angela Y. Davis (2005) and the contemporary prison abolition movement.

Second, in public discussion about reparations to Black Americans, transitional justice is an infrequently used but powerful concept. Those who advocate including Global North nations in transitional justice's scope are at least in part motivated by the objectionableness of marking out "emerging democracies" that require transitional justice in order to become like "established democracies," where the concerns of transitional justice ostensibly do not apply (e.g., Hansen 2011, p. 40). Against the backdrop of a racial ideology "that blames Blacks themselves for their poorer relative economic standing, seeing it as the function of perceived cultural inferiority" instead of an unjust and dysfunctional sociopolitical order, there is rhetorical power in showing what the present-day United States has in common with pre-transitional contexts that are widely recognized as such (Bobo and Kleugel, 1997, p. 95).

\section{Transitional Justice in the United States?}

Let us begin by looking more closely at the question of whether Global North countries can be characterized as "transitional." Authors like Andrew Valls (2003), Stephen Winter (2014), and ourselves (King and Page, 2018) have argued that the tools of transitional justice-truth commissions, reparations, memorialization and memory projects, political 
apologies, and so on-can help these nations grapple with legacies of violence and exclusion. Using these tools, a society with formally democratic features, such as democratic elections, can work toward becoming a more substantive democracy. Adjoa A. Aiyetoro (2011) makes the formal-substantive democracy distinction in the context of the United States. Though Black voter suppression is a continuing threat to the formal democratic status of U.S. elections (Anderson 2018), elections take place at regular, predictable intervals. Notwithstanding the January 6, 2021 attack on the Capitol and the White supremacist politics that fueled it (Nevius 2021; Smith and King, 2021), so do transitions of power. However, Aiyetoro (2011) points out, while "many tout the United States as being the most advanced democracy... significant portions of its citizens are living under conditions or vestiges of oppression" (p. 635). True democracy requires substantive democracy, she argues, and "substantive democracy requires each citizen to be valued and heard equally" (p. 636). This is far from the case for the descendants of enslaved persons, but Aiyetoro thinks reparations are a promising pathway to the United States becoming a substantive democracy.

Though Aiyetoro's aim is to lay out an argument for reparations for Black Americans, not to provide a theory of transitional justice, her formal-substantive democracy distinction offers a way in which the United States might be thought of as a transitional political context. But many scholars understand transitional justice as explicitly concerned with the context of a formal democratic regime change. Harry Hobbs (2016) characterizes the field of transitional justice as "wedded to the paradigmatic transition-a liberal democratic state rising from the ashes of a collapsed authoritarian regime" (p. 512). ${ }^{1}$ This is the context Ruti G. Teitel (2014) was thinking of in her writings that brought the term "transitional justice" to mainstream scholarly attention in the early 1990s; the same goes for Neil J. Kritz's (1995) four-volume Transitional Fustice: How Emerging Democracies Reckon with Former Regimes (Arthur 2009). Alexandra Barahona de Brito and colleagues (2001) similarly understand transitional justice as addressing the "legacies of repression" that "societies face during a transition from authoritarian or totalitarian to democratic rule" (p. 1). Some definitions, however, see the requirement of a democratic regime change as too narrow, recognizing that in practice, questions of transitional justice can arise after civil or international wars, and that a regime change with democratic aspirations does not necessarily produce democracy. For Anja Mihr (2021), transitional justice is "a concept and a process that encompasses a number of different legal, political, and cultural instruments and mechanisms that can strengthen, weaken, enhance, or accelerate processes of regime change and consolidation" (p. 1). Alice MacLachlan and Allen Speight (2013) see transitional justice's context as the aftermath "of conflict or regime change, [when] political actors confront questions of individual and collective responsibility — and thus, the need for accountability and legal justice-without stable, recognizable sources of legal and political authority to draw upon" (p. 3). ${ }^{2}$

A recent book by Murphy (2017) is one of the most thoroughgoing theoretical efforts to conceptualize transitional justice. As Murphy argues, transitional justice isn't only about the mechanisms that are commonly associated with it. Rather, it is a distinct form of justice that can be achieved (or not) in the domain to which it is specific. Just as distributive justice concerns the domain of how goods and opportunities are allocated and corrective justice concerns the domain of civil wrongs, transitional justice concerns the "just pursuit of societal transformation" (Murphy 2017, p. 112). Paradigmatic transitional contexts include the end of apartheid rule in South Africa, the end of the Bosnian War, and the recent peace agreement between the Colombian government and The Revolutionary Armed Forces of Colombia (FARC) (cf. Ní Aoláin and Campbell, 2005, pp. 179-182). In such contexts, whether the future will bring stability or a reemergence of past violence is a genuinely uncertain matter-one study shows that ninety percent of civil wars in the 2000 s are the 
resumption of civil wars that had previously ended (Walter 2015). What happens in the transition period can thus play an important role in promoting a lasting peace. According to Murphy (2017), transitional justice aims at transforming societies characterized by four necessary conditions: normalized collective and political wrongdoing, pervasive structural inequality, serious existential uncertainty, and fundamental uncertainty about authority.

Authors who think that the tools of transitional justice can be applied without considering the current United States a bona fide transitional context have a point: These tools are valuable ways of addressing past and present injustice. At the same time, explicitly considering commonalities between paradigmatic transitional contexts and the United States can ground a penetrating critique of the latter-in particular its imprisonment and policing regime. Two of Murphy's criteria-normalized collective and political wrongdoing and pervasive structural inequality - apply straightforwardly to the political situation of low-income African American communities under this regime, as does as a third criterion-failure of the rule of law.

\section{Conceptualizing the U.S. Imprisonment and Policing Regime}

\section{Normalized Collective and Political Wrongdoing}

Murphy (2017) defines normalized collective and political wrongdoing as "the actions or omissions of particular human beings that result in violations of human rights" (pp. 49-50). Such wrongdoing often targets members of structurally disadvantaged groups- "the vulnerability to abuse and human rights violations increases when there is an absence of minimum level of respect and recognition of the humanity of members of a certain group" (Murphy 2017, p. 61).

Police killings and violence towards Black Americans are a visible example of normalized collective and political wrongdoing. Consider the findings of a 1998 Human Rights Watch report of the United States:

Police abuse remains one of the most serious and divisive human rights violations in the United States. The excessive use of force by police officers, including unjustified shootings, severe beatings, fatal chokings, and rough treatment, persists because overwhelming barriers to accountability make it possible for officers who commit human rights violations to escape due punishment and often to repeat their offenses. Police or public officials greet each new report of brutality with denials or explain that the act was an aberration, while the administrative and criminal systems that should deter these abuses by holding officers accountable instead virtually guarantee them impunity....

In the cities we have examined where such data are available, minorities have alleged human rights violations by police more frequently than White residents and far out of proportion to their representation in those cities. Police have subjected minorities to apparently discriminatory treatment and have physically abused minorities while using racial epithets. Mistreatment may be non-violent harassment and humiliation... At worst, it includes the kinds of extreme violence we feature in this report (Human Rights Watch 1998, pp. 25, 39).

Little has changed in subsequent decades. A report of the United Nations Working Group of Experts on People of African Descent in 2016 identified "alarming levels of police brutality and excessive use of lethal force by law enforcement officials, committed with impunity against people of African descent in the United States" (UNHRC 2016, p. 7). 
Researchers have found that Black men face a 2.5 times higher risk of being killed by police compared to their White male counterparts, and a 1 in 1000 risk overall (Edwards et al., 2019). Moreover, killings by police are "only the tip of the iceberg in what is a pervasive racial bias in the justice system," according to the United Nations report (2016, p. 8). Testimonies of Black Americans revealed "a pattern of police practices which violate their human rights: they are disproportionately targeted for police surveillance, and experience and witness public harassment, excessive force, and racial discrimination" (UNHRC 2016, p. 8).

When it comes to Murphy's concept of normalized collective and political wrongdoing, "normalized" is a key aspect. When state violence is normalized, it is not a matter of bad apple officials acting on their own. Rather, the laws, institutional rules, and norms governing their conduct promote wrongful behavior (Alexander 2010; Bobo and Thompson, 2010; Butler 2016, 2017; Carbado 2017; Obasogie and Newman, 2018, 2019; Obasogie 2020; Roberts 2007). The cornerstone of Supreme Court jurisprudence on police excessive force, Graham v. Connor (1989), is an illustrative example. Rather than giving clear guidelines about when the use of force by police officers violates the Fourth Amendment rights of individuals (Obasogie and Newman, 2019), Graham (1989) instead lays out a standard where the use of force should be judged "from the perspective of a reasonable officer on the scene" (p. 396). The standard purports to be objective, and references the seriousness of the crime, the threat posed by the suspect to the officers or others, and non-compliance by the suspect as factors relevant to assessing whether an officer used force reasonably (Graham 1989). At the same time, it is designed to give weight to "the fact that police officers are often forced to make split-second judgments-in circumstances that are tense, uncertain, and rapidly evolving-about the amount of force that is necessary in a particular situation"; the ruling explicitly cautions against evaluating police decisions "with the 20/20 vision of hindsight" (Grabam 1989, p. 396). This creates a presumption where a police officer's judgment is not second-guessed by the court. Even though Graham overturns a prior ruling, Fobnson v. Glick (1973), rejecting its requirement of an officer's bad intent, it agrees with Fobnson that "Not every push or shove, even if it may later seem unnecessary in the peace of a judge's chambers'... violates the Fourth Amendment" (Graham 1989, pp. 396-397).

The latitude Graham gives police is captured by the circumstances and outcome of the case itself. Dethorne Graham, a diabetic Black man, was experiencing an insulin shock, went into a store to buy orange juice, but left because the line was too long. Charlotte police found this suspicious, and confronted and arrested Graham. The Court makes no mention of Graham's resisting arrest—indeed, Graham passed out before he was handcuffed-but the officers' rough treatment resulted in "a broken foot, cuts on his wrists, a bruised forehead, and an injured shoulder" (Grabam 1989, p. 390). On remand, a jury took up the Supreme Court's newly-minted standard and found that the police had acted reasonably (Obasogie 2020).

Police interactions are not the only context where African Americans face normalized human rights violations under the U.S. imprisonment and policing regime. A report by the American Civil Liberties Union of Eastern Mississippi, Suffering in Silence: Human Rights Abuses in St. Louis Correctional Centers (2009), relies on the testimony of corrections officers and emergency medical technicians to detail physical and sexual abuse by their colleagues, overcrowded and squalid living conditions, medical inattention, and-inexplicably-the practice of forcing inmates to sit naked in freezing cells during winter months. Alabama state prisons were the subject of a recent U.S. Department of Justice investigation (DOJ 2019), which found systemic failures by the Alabama Department of Corrections to prevent and investigate prisoner-on-prisoner violence, including sexual violence, that often went unreported. This in part resulted from understaffing and the inadequate supervision of 
prisoners. The DOJ reports of prisoners being "tied up for days" without corrections officers noticing; one prisoner found by guards couldn't talk due to injuries to his mouth and required an emergency surgery to remove a rectally-inserted broomstick (DOJ 2019). To the extent that deaths are tracked, the homicide rate in Alabama prisons is eight times the national level (DOJ 2019).

Harsh prison conditions are not only for those convicted of crimes; there is also the matter of pretrial detention. Infamously, sixteen-year-old Kalief Browder was accused of stealing a backpack and arrested. He maintained his innocence and spent almost three years awaiting his trial in the Rikers Island prison complex. There Browder endured beatings by corrections officers and other inmates and two years of solitary confinement; after his release, he committed suicide (Schwirtz and Winerip, 2015). One study shows that the average cost of bail is $\$ 2,786$ for misdemeanor detainees (Heaton et al., 2017). Of the halfmillion people in pretrial detention in the United States, $43 \%$ are Black (Sawyer 2019).

Perhaps controversially, excessive punishment itself might fall under the heading of normalized collective and political wrongdoing. Mirko Bagaric and colleagues (2017) argue that long prison terms are so threatening to what human rights discourse aims to secure for all human beings that over-imprisonment is a human rights abuse. They make the point that long-term prisoners cannot procreate and are severely restricted in how they participate in family life. Many deemed China's longtime one-child policy an "assault on human rights" (Tai 2016). Why isn't the situation of long-term prisoners considered thusly? Long prison sentences are also associated with reduced education and employment prospects and lower life expectancy (Bagaric et al, 2017), as well as formal collateral consequences such as restrictions on political participation and public housing benefits (Travis 2002). ${ }^{3}$ These are the precise kinds of deprivations with which human rights frameworks are concerned.

\section{Pervasive Structural Inequality}

Even if one rejects the view that over-imprisonment itself counts as normalized collective and political wrongdoing, incarceration is deeply linked to another one of Murphy's criteria for identifying transitional contexts-pervasive structural inequality. Here, individuals are "differentially limited in the range of opportunities they can feasibly achieve" (Murphy 2017, p. 46). Scholars have found that poor Black children have extremely low rates of mobility, something not explained by class alone. Those coming from homes in the bottom quintile of household income have a $2.5 \%$ chance of making it to the top quintile, whereas White children born into the bottom quintile have a $10.6 \%$ chance (Chetty et al., 2020). A study by Bruce Western (2002) links income inequality and incarceration: Serving time in prison hinders the development of job skills, creates the stigma of having a criminal record, and makes it hard for individuals to form or maintain employment networks. As Western shows, the income inequality-incarceration link is empirically demonstrable and partially explains the Black-White earnings gap since African Americans face disproportionate imprisonment rates. As of 2018, this was five times the rate of White Americans; for Black men ages thirty-five to thirty-nine, one in twenty were in federal or state prison (Gramlich 2020).

In addition to facing inequalities in mobility, income, and incarceration-combined with inequalities in wealth (Oliver and Shapiro, 2006), education (Orfield and Frankenberg, 2014), and health and life expectancy (Jackman and Shauman, 2019)_Black residents of segregated, high-poverty communities do not interact with state officials on the same terms as their White, well-to-do counterparts, something Murphy (2017) identifies as fundamental to a structurally equal society. Monica C. Bell's (2017) theory of legal estrangement encapsulates Murphy's point perfectly. Bell contests the common idea that 
poor Black Americans are second-class citizens in U.S. society: Overpoliced and underprotected by law enforcement institutions, "these groups often see themselves as essentially stateless - unprotected by the law and its enforcers and marginal to the project of making American society" (Bell 2017, p. 2057). Legal estrangement describes the collective sense of anomie within marginalized Black communities towards the legal and criminal justice system, paired with the material realities that give rise to anomic group consciousness.

To bring the theoretical concept of legal estrangement to life, Bell tells the story of a Shawna, a youth raised in Gilmor Homes in West Baltimore. An avid basketball player, Shawna was accustomed to games being interrupted by gun violence. When she was younger, she had wanted to be a police officer, but as she grew older, she heard stories of police violence, including sexual assault by a police officer, in her community. She also had negative experiences with police that have led her to avoid West Baltimore's main shopping center, Mondawmin Mall. These negative experiences would not garner "the attention of journalists, researchers, or most advocates," says Bell (2017, p. 2095).

She has experienced, at most, (possibly idle) threats-that the next time a police officer sees her, he will mace or even arrest her. These threats, these forceful words, would not register as "uses of force" in the most sophisticated studies of police encounters. Yet they have constrained her movement (Bell 2017, p. 2095).

As James Forman, Jr. (2017) similarly observes:

Swearing and yelling, making belittling remarks, issuing illegitimate orders, conducting random and unwarranted searches, demanding that suspects "get against the wall" - these behaviors rarely led to lawsuits or newspaper coverage. But for residents of the city's poorest neighborhoods, especially young people, this treatment became part of the social contract, a tax paid in exchange for the right to move in public spaces (p. 171).

Bell (2017) characterizes Shawna as "a thoughtful young woman who has never had any serious police encounter, who has managed to avoid getting a criminal record, and who is a general law-abider, wanting to trust the police but convinced that the police are not trustworthy for people like her" (p. 2099). At the same time, Shawna's alienation towards law enforcement is pronounced — and she no longer wants to be a police officer. "Although Shawna sees the law and its enforcers as worthy of obedience as a theoretical matter," Bell writes, "she does not believe that law enforcement officials see her, and people like her, as a true part of the polity" (2017, p. 2099).

Accordingly, the structural inequalities between poor Black Americans and their more privileged counterparts should not only be conceptualized in terms of statistical measures of wellbeing, but also in the nature of the relationships between these groups and state institutions. Unequal relationships are not only a matter of practice, but also of law. Paul Butler (2017) makes this point in his analysis of the Supreme Court case Illinois v. Wardlow (2000). The Court had to decide whether police could detain and search an individual who they hadn't suspected of a crime, but who runs away upon seeing an officer. They ruled that this practice is legal in high-crime areas- "which almost always means minority communities"-and nowhere else (Butler 2017, p. 109). This amounts to unequal legal rights: The resident of a middle-income White neighborhood who attempts to evade a police officer has a legal right against being searched, but a resident of a low-income Black neighborhood does not. 
Traffic stops are a related element of the U.S. imprisonment and policing regime where African Americans experience structural inequalities. Recent research shows that Black drivers are twice as likely to be pulled over as White drivers (even though White people drive more), and four times as likely to be searched by police (Baumgartner et al., 2018). Unsurprisingly, while White Americans report feeling that traffic stops are fair and reasonable, disproportionate stops make Black Americans feel that "they are not regarded as full and equal members of society" (Epp et al., 2014, p. 16). Many respond by avoiding driving in certain places and changing what clothes they wear. "The notorious pass laws in South Africa under apartheid, which allowed Black people into White areas only if carrying a pass authorizing entry, worked a similar evil," write Charles R. Epp and colleagues, "and no amount of professional courtesy and respectfulness can hide the deep violation at the core of this practice" (2014, p. 16).

A final example of the structural inequalities that African Americans face relates to what Dorothy E. Roberts (2003) and others call “community harms.” Race plays an outsized role in the relative likelihood that one has a family member, friend, acquaintance, or neighbor who is imprisoned. A study by Hedwig Lee and colleagues (2015) shows that Black men have incarcerated acquaintances and neighbors at a rate five times higher than White men. Black women experience the imprisonment of family members at a rate eleven times that of White women, meaning that close to half of Black women have one or more relatives serving a prison sentence. Roberts (2003) describes the psychological and emotional toll that results: "Dealing with an incarcerated relative causes stress, both from worry about the inmate's well-being and from tension among relatives as they struggle to survive the ordeal. These enormous burdens fall primarily on the shoulders of women caregivers, who customarily shore up families experiencing extreme hardship" (p. 1282). This reality is unsurprising, given the very concept of mass incarceration-viz., a criminal justice system in which, as per David Garland's (2001) seminal definition, "it ceases to be the incarceration of individual offenders and becomes the systematic imprisonment of whole groups of the population” (p. 2).

\section{Failure of the Rule of Law}

Murphy (2017) does not formally list rule-of-law failure as one of her criteria for identifying transitional contexts, but it nevertheless plays an important analytic role as an aspect of pervasive structural inequality. Securing the rule of law is a necessary, but not sufficient, condition for overcoming pervasive structural inequality and achieving a just societal transformation (Murphy 2017). For our purposes, discussing rule-of-law failure in lowincome Black communities highlights a distinctive third commonality between the U.S. context and traditional transitional contexts.

The rule of law is an essential part of any stable and legitimate political order. When the rule of law is present, this allows political subjects to make informed decisions concerning their own conduct and its legality. Here, it is widely known what the law is and the ways in which it will be enforced. If you, as a political subject, want to avoid engaging in illegal activities, chances are that you will know how to avoid engaging in illegal activities: Don't commit crimes and the criminal justice apparatus of the state will not bother you. "When the requirements of the rule of law are respected, legal rules shape the general contour of political relationships..." Murphy (2017) writes. "When declared legal rules actually govern conduct, citizens can... form reliable expectations, based on legal rules, of how other citizens and officials will respond to their actions" (p. 124).

There are many ways in which the U.S. imprisonment and policing regime falls short of instantiating the rule of law, especially in low-income African American communities. 
Given that the present-day imprisonment and policing regime in the United States is closely linked to a longstanding "law and order" ideology, this is cruelly ironic (Alexander 2010; Hinton 2016; Murakawa 2008, 2014). Thomas Hobbes ([1651]1994), once characterized good laws as "needful, for the good of the people, and withal perspicuous" (p. 229). Many misdemeanor statutes in the United States fail the Hobbesian standard. Take \$18.2322 of the Virginia Code, which makes public spitting a Class 4 misdemeanor. Spitting on a sidewalk may be gross, but it is not harmful, and importantly, is not the kind of thing that individuals typically think about when they reflect on what the law prohibits. Yet laws against public spitting and other order maintenance laws converge into a body of criminalized conduct that is extremely large. The scale of order-maintenance offenses is such that they could never be regularly enforced across the broader U.S. population without this smacking of totalitarian rule. Instead, enforcement is a matter of police discretion. Individual officers are licensed to arrest individuals for extremely arbitrary and subjective reasons in West Baltimore, where Shawna lives, and other communities like it—a hallmark indicator of the absence of the rule of law.

An important recent study by Alexandra Natapoff (2018) is devoted to the arbitrariness of the U.S. misdemeanor system. Natapoff provides case after case of individuals arrested and punished for conduct that no reasonable person would imagine to be legally culpable. Sometimes individuals are arrested for minor, selectively-enforced order-maintenance offenses. Sometimes a police officer interprets perfectly innocuous and legal conduct as something other than what it is. An arrest is then made, the accused pressured into a guilty plea or convicted for a misdemeanor by a judge in less than three minutes (Natapoff 2018). The lived reality of law-and-order-driven rule-of-law failure is harsh. A misdemeanor conviction may mean losing a driver's license or a brief prison stay, which can easily lead to the loss of employment. A criminal record, even if one misdemeanor is the only item on it, can be grounds for rejecting a job applicant. Fines and court fees can be prohibitively expensive for a low-wage earner, and a failure to pay can have big consequences-more fines, an arrest warrant in your name, and jail time. "In this manner," Natapoff writes, "the misdemeanor process confers relatively unfettered authority on police to formally transform Black men into petty criminals based on minor, often harmless conduct, and sometimes even when they are doing nothing at all” (2018, p. 157).

Rule-of-law failure is often associated with corrupt state officials. This kind of corruption is certainly reported in the United States. In an interview study of youths living on Chicago's South Side, a teen named Christopher describes an encounter with police where "They stopped us, and they asked me where the fuck I'm going. Then that's when they went in my pockets, threw my keys, and took my money" (Futterman et al., 2016, p. 134). A recent book by Baltimore Sun journalist Justin Fenton (2021) is devoted to Baltimore police sergeant Wayne Jenkins and other members of the elite Gun Trace Task Force, whose crimes included the targeted theft of money and drugs from victims deliberately chosen for their perceived lack of epistemic credentials.

However, it might also be construed as a failure of the rule of law when fines and court fees make up significant municipal revenue streams. The Department of Justice's patternor-practice investigation of the Ferguson, MO police department notoriously found that Ferguson municipal court's "primary goal" was not "administering justice or protecting the rights of the accused," but rather, funding the city coffers: "City, police, and court officials for years have worked in concert to maximize revenue at every stage of the enforcement process, beginning with how fines and fine enforcement processes are established" (DOJ 2015 , pp. 42, 10). Here the municipal code itself plays a key role, "address[ing] nearly every aspect of civic life for those who live in Ferguson"-for example, barking and off-leash dogs and grass that grows too high (DOJ 2015, p. 7). (Again, Thomas Hobbes: "Unnecessary laws are not good laws; but traps for money" ([1651]1994, p. 229).) Researchers have found 
that the more time police devote to collecting revenue, the less violence and property crime are addressed (Goldstein et al., 2020). There is, moreover, a strong correlation between a city's reliance on fines and fees for revenue generation and the percentage of residents who are Black (Sances and You, 2017; Singla et al., 2020).

Another source of revenue is the practice of civil asset forfeiture. Colloquially referred to as "legal larceny," civil asset forfeiture allows a person's property to be seized if police allege that it has been used in the commission of a crime. A 2015 Institute for Justice report uses the example of Philadelphia to describe how a city can serve as "a forfeiture machine":

Pennsylvania state law enables agencies to retain 100 percent of the value of forfeited property, and law enforcement in Philadelphia took in more than $\$ 69$ million between 2002 and 2013. That total comprises more than 1200 houses, 3400 vehicles, $\$ 47$ million in cash, and various other items, such as electronics and jewelry. The total also represents almost one-fifth of the district attorney's general, appropriated budget. With those funds, Philadelphia has paid for equipment, maintenance, education and training, and salaries of personnel, this last of which represents the most direct conflict of interest for the unbiased administration of justice. Conspicuously, Philadelphia spent none of its forfeiture funds on proactive, community-based anti-drug and crime prevention programs, despite proponents' claims that forfeiture funds are essential to supporting such efforts (Carpenter et al., 2015, p. 16).

The report also tells the story of Charles Clarke, a Black college student whose life savings were taken by police who searched him for marijuana at the airport. Clarke carried $\$ 11,000$ on him because he was in the middle of moving and didn't have a bank in the area to deposit it in, but officers didn't believe him. Though they charged him with no crimes-there was no evidence he had committed any-taking his money didn't require this (Carpenter et al., 2015). Fortunately for Clarke, the Institute for Justice, a libertarian public interest law firm, took on his case pro bono and got his money back (Institute for Justice 2016). Many other individuals in his position are not so lucky. Legal fees can be higher than the value of the seized assets themselves, and the most common standard of proof in civil forfeiture cases is a preponderance-of-evidence standard, setting an extremely low bar for the government to prove its case (Carpenter et al., 2015). The rule-of-law failure that legal larceny represents is hardly colorblind: a recent study of 2278 police departments across the United States found that the forfeiture revenue of cities correlates strongly with the percentage of residents who are racial minorities (Nicholson-Crotty et al., 2021).

\section{Is the United States a Transitional Political Context?}

The U.S. imprisonment and policing regime has been characterized as involving normalized collective and political wrongdoing, pervasive structural inequality, and the failure of the rule of law. Such an institutional order is seriously deficient from the standpoint of justice, so much so that "there exists a right to rebel" (Murphy 2017, p. 47). In his book on the political ethics of urban ghettos, Tommie Shelby (2016) argues this point at length. When the Black residents of segregated inner-city neighborhoods "engage in criminal activity or show contempt for legal requirements and law enforcement officials, this is widely regarded as a blameworthy failure of reciprocity on their part," Shelby observes, but "no citizen can be expected to tolerate serious, burdensome, and repeated injustices over the course of their lives" (2016, pp. 214-215). Shelby draws on John Rawls' ideal of society as a fair system of social cooperation, something that undergirds the legitimacy of the state's claim to political authority and the obligations of individuals to comply with the law. A 
Rawlsian framework suggests that if the basic structure of society is deeply unjust, for those unjustly disadvantaged, there is no binding duty of obedience to the law, and self-respect may even require out-and-out defiance of it (Shelby 2016).

If normalized collective and political wrongdoing, pervasive structural inequality, and the failure of the rule of law are features of a deeply unjust regime-to such an extent that they generate a right of disobedience-are these features also sufficient to consider the United States a transitional political context? Murphy (2017) posits two additional criteria — serious existential uncertainty and fundamental uncertainty about autbority — for identifying transitional societies. Let us consider each in turn.

\section{Serious Existential Uncertainty}

The category of serious existential uncertainty refers to the idea that transitions sometimes result from the cessation of war or negotiations between representatives of warring groups. Here, it is widely understood to be a tense and fragile political moment, where it is unclear "whether a particular moment is the temporary turbulence of the ancient regime or really a break that might lead somewhere new" (Murphy 2017, p. 67). At first glance, the idea of serious existential uncertainty seems potentially fitting as a description of the racial justice protests of Freedom Summer 2020. The peaceful demonstrations that erupted across the United States and worldwide after George Floyd's death in Minneapolis saw clashes between law enforcement and protesters. Vandalism and rioting broke out, with the left blaming right-wing extremists who showed up and the right blaming leftist anarchists and antifa (MacFarquhar 2020). Against this backdrop, there were calls to defund the police that seemed to move some public officials and law enforcement budget cuts were implemented. There seemed to be the possibility of transformative change, with protestors telling the press, "This time is different" (Sobey 2020).

If a complete overhaul of the U.S. imprisonment and policing regime comes about, then surely the protests of 2020 will go down in the history books as a crucial moment in the transition. Many states are undertaking police reform, and at the time of this writing, the Department of Justice's current budget proposal shows attempts to reduce racial profiling, excessive force, and practices like "no-knock" warrants (Jenkins 2021; Treisman 2021; Wilson 2021). Furthermore, the prison population in the United States has been in gradual decline since 2009. However, though some experts decreed "the beginning of the end of mass incarceration" (Goode 2013), more recent analyses show that the current rate of decline is not enough to change the overall fact of mass incarceration (Ghandnoosh 2020; see also Martin and Price, 2016). Dismantling mass incarceration would seem to need to be a matter of public policy, undertaken at the state, federal, and local levels, deliberately aimed at this end (Epperson and Pettus-Davis, 2017). Todd R. Clear (2021) puts the matter succinctly: " $[\mathrm{A}] \mathrm{s}$ a matter of policy, we determine how many people are in prison. If we want a smaller prison population in the United States, we should send fewer people to prison, and make the stays of those we send to prison shorter" (p. 257). Evelyn J. Patterson (2017) emphasizes the importance of sending fewer people to prison-via decriminalization and alternative sentencing practices — as her model shows shortening prison stays to have only a modest effect on reducing the prison population size.

There is some evidence emerging of the political will for ending mass incarceration. A 2015 book features essays critical of mass incarceration from politicians across the political spectrum, including conservative figures like Ted Cruz, Marco Rubio, and Scott Walker (Chettiar and Waldman, 2015). "Our nation is beginning to understand certain fundamental truths," reads the volume's introduction. "Mass incarceration exists. It is not needed to keep down crime. It comes at a huge cost to the country. And there are practical 
solutions on which we can agree to reduce our prison population, while keeping the country safe" (Chettiar and Waldman, 2015, p. 1; but see Gilmore 2015). However, as Peter K. Enns (2016) argues, the problem is not just politicians. It is also a punitive American public. The end of mass incarceration is unlikely if U.S. voters remain committed to a punishment paradigm and fail to see crime as a public health problem (Pfaff 2017). Of course, the latter is easier when drug crimes are the issue; it is much harder when the issue is violent crime, with its tangible, sometimes life-altering impact on the lives of victims. Indeed, violent crime is on the rise, a political liability for Democrats (Olsen 2021). While journalists question the wisdom of the idea of defunding the police, a number of cities are reversing the budget cuts they had made (Jamerson 2021).

In light of all this, does U.S. society qualify as a society that is experiencing serious existential uncertainty? It seems that this judgment would be premature at the moment. We might imagine a future where U.S. voters and public officials no longer saw the solution to violence as more violence, where there were deep, long-term policy commitments to decarceration and depolicing across the nation. Here, a number of existential questions would likely arise. Would there be the political will, energy, and resources for providing mental health care, education access, and job opportunities in communities that are currently underserved and overpoliced? Would underlying structural inequalities be transformed? If crime rates increased, would a decarceration and depolicing regime be hastily replaced with a return to the "law and order" days of old? As we read Murphy, this is the kind of political context that would indicate that the United States is truly a society in transition, not our current one, where the grip of the present imprisonment and policing regime remains strong.

\section{Fundamental Uncertainty about Authority}

This brings us to Murphy's other category, fundamental uncertainty about authority. Here, the United States seems to depart strongly from paradigm transitional contextsthe category describes political situations where "citizens and sometimes officials in transitional circumstances do not assume, and indeed in some cases openly question and challenge, the authority of the new government" (Murphy 2017, p. 74). Though numerous examples could be brought in as illustrations, take just one-that of East Timor. Colonized by Portugal in the sixteenth century, East Timor declared independence in 1975 but was immediately annexed by Indonesia. A military occupation ensued; subsequent decades saw the killings of civilians and protestors, displacement, forced starvation, torture, and military sex slavery. An increasingly organized East Timorese resistance movement, a new Indonesian president, and a series of diplomatic negotiations led to an UN-sponsored independence vote on August 30, 1999, where the people of Timor-Leste overwhelmingly voted to break from Indonesia. The military responded with what Jovana Davidovic (2012) characterizes as a scorched-earth response: "Close to half of East Timor's population was displaced, over seventy percent of all infrastructure was destroyed, and 1300 people were killed in the violence that erupted prior to and after the vote" (p. 84). Australian military and UN security forces staged a successful humanitarian intervention, and in October 1999, helped establish a transitional administration which held power until 2002. In May of that year, a parliamentary government took over, completing the East Timorese independence process (see Auweraert 2012; Davidovic 2012; Evans 2012; Fernandes 2010).

Though normalized collective and political wrongdoing, pervasive structural inequality, and the failure of the rule of law long characterized East Timor, two political periods referenced above reveal fundamental uncertainty about authority. The first is in the mid-1970s, when East Timor rapidly went from being a Portuguese colony to an 
independent nation to an Indonesian occupied territory. The second is the period from 1999 to 2002. It looked like the independence vote outcome would be violently repressed until international security forces intervened. Fragile political circumstances were then overseen by two governments, the United Nations Transitional Administration in East Timor and the Democratic Republic of Timor-Leste, before the political situation stabilized under the latter. On Murphy's understanding, these two periods are appropriately characterized as transitional. The first, of course, resulted in further upheaval and repression, while the second brought the independence the East Timorese people had for so long sought.

It is valuable to identify what is distinctive about political contexts like East Timor's and to distinguish these from contexts like that of the United States. In East Timor, there were a clear and identifiable regime changes that created a "uniquely liminal moment" between the past and future (Gray 2010, p. 62). When transitional justice mechanisms were implemented to provide truth, accountability, and reparations for the violent abuses associated with the Indonesian military occupation, there was a widespread understanding that the days of military rule were over. Of course, the transition did not assure the end of violence: The first few years of independence saw riots and political volatility, and in 2006, an attempted coup resulted in over three dozen deaths and the destruction of over a thousand homes (Auweraert 2012). Nevertheless, as a clear-cut empirical matter, a regime change had taken place. However, if no regime change occurs, using the tools of transitional justice in order to construct a liminal moment between the past and future risks superficiality. ${ }^{4}$ In Red Skin, White Masks: Rejecting the Colonial Politics of Recognition, Glen Sean Coulthard (2014) is critical of the Truth and Reconciliation Commission of Canada and Prime Minister Stephen Harper's 2008 apology. Both treated residential school abuses as part of an unjust past while remaining silent on the present injustice of denying Indigenous nations a land base and political self-determination. As such, Canada's program of transitional justice buttressed an illusory narrative asserting that its injustices towards First Nations, Inuit, and Métis peoples were the product of a bygone illiberal era, and that there had at one point been a regime change: In fact, settler-colonialism was and is very much the Canadian modus operandi. Importantly, the issue wasn't simply a matter of acknowledging the past while failing to acknowledge the present. Acknowledgment can only go so far. If Canada had recognized its colonial present, this would not have been the same as decolonization (Fisher 2021).

Increasingly in the United States, the tools of transitional justice are cited as the appropriate response to the country's imprisonment and policing regime, as well as to structural and institutional anti-Black racism more broadly. In 2015, the city of Chicago passed a reparations ordinance containing material and symbolic forms of redress for the African American victims of police torture-suffocation and electric shocks were among the methods used to forcibly extract confessions-in the 1970s and 1980s (Taylor 2016). Bryan Stevenson (2017), founder and director of the Equal Justice Initiative, advocates a national "process of truth and reparation" as the appropriate way of addressing mass incarceration (p. 4). Journalist Juleyka Lantigua Williams (2018) proposes layered reparations and an official apology to persons whose socioeconomic background led to their imprisonment. Others advocate for municipalities to pay reparations to the families of victims of police killings (Page 2019); there is also discussion of Drug War reparations (Flanigan and Freiman, 2020).

The most prominent proposed path to federal-level reparations for slavery, Jim Crow, and present-day structures of anti-Black racism is laid out in the bill H.R. 40. Introduced in the House of Representatives every Congressional session since 1989, H.R. 40 would set up a commission to study proposals for reparations to African Americans (Congress.gov 2021a, 2021b). The current version has 188 cosponsors, more than at any other point in 
the bill's history, and hearings were held on it in 2019 and 2021. Another Congressional resolution aims at establishing a U.S. Commission on Truth, Racial Healing, and Transformation (Congress.gov 2021c, 2021d). A 2019 Business Insider poll found support for reparations among 54\% of survey respondents identifying as moderately or very liberal, suggesting a sizeable shift among a share of White liberals in recent times (Haltiwanger and Hickey, 2019; cf. Dawson and Popoff, 2004). State and local efforts around truth and reparation are currently taking place in Maryland, California, Evanston, IL, Chicago, IL, Asheville, NC, Burlington, VT, Amherst, MA, and Providence, RI (O'Brien and Ax, 2021).

There is little doubt that the progress towards reparations is a momentous achievement on the part of reparations advocates and activists, especially considering the U.S. government's longstanding refusal of redress to formerly enslaved people and their descendants (Berry 2005; Boxill 2003). But there is a danger of seizing upon the tools of transitional justice- the promise of truth and reparation-as a way of reckoning with the past and present without simultaneously undertaking measures that constitute a genuine break with both. In this respect, it is worth emphasizing the ways in which the present-day United States is not transitional political context. To deny that the United States is currently in a moment of transition is to call attention to the insufficiency of existing efforts to move away from its imprisonment and policing regime. "It may be normatively desirable to end repressive regimes and longstanding conflicts," Murphy writes, "but a society is only transitional when there are efforts taken to realize this end" (2017, p. 70).

\section{Regime Change in the United States and Abolition Democracy}

When transitional injustice mechanisms such as truth-telling and reparations programs are implemented in the Global North, the context is not that of a traditional regime change, where one government dissolves and a newly-constituted government replaces it. It is worth concluding our analysis with a discussion of what a genuine transition would look like in Global North countries - an area of the transitional justice literature that is greatly undertheorized, we should add. Is it even meaningful to use the language of "regime change"?

In our view, it is. The word "regime" has different meanings: It can mean a government, and also, a way of doing things. This latter sense of "regime" is closely connected to what American Political Development scholars refer to as an "institutional order"-viz., "a coalition of governing state institutions, nonstate political institutions, and political actors that is bound together by broadly similar senses of the goals, rules, roles and boundaries that members... wish to see shaping political life" (King and Smith, 2005, p. 78). For Desmond King and Rogers M. Smith (2005), there is never just one institutional order operating at a given time. Rather, competing institutional orders form the backdrop to politically contested issues. Competition between two salient racial institutional orders-a "White supremacist" order and an "egalitarian transformative" order- "explain[s] many features of American politics that may appear unrelated to race, such as congressional organization, bureaucratic autonomy, and modern immigration priorities," they argue (King and Smith, 2005, p. 78). At the same time, one racial institutional order may completely dominate the other in a given political arena, such as that of the criminal justice system. When an institutional order is dominant, it helps form and maintain a regime manifesting its internal logic. In the criminal justice context, a White supremacist racial institutional order-and its successor, an "antitransformative" racial order that has responded to racial egalitarianism's "bar[ring] the deployment of overtly white supremacist language" (King and Smith, 2005, p. 84)-have undergirded what we have been calling the U.S. imprisonment and policing regime. 
Many scholars have argued for the centrality of race in explaining the rise of U.S. mass incarceration beginning in the 1970s. Prior to this decade, crime rates were going up, but as Jeremy Travis and colleagues (2014) argue, "the best single proximate explanation of the rise in incarceration is not rising crime rates, but the policy choices made by legislators to greatly increase the use of imprisonment as a response to crime" (p. 3). On Vesla M. Weaver's (2007) theory, the policy choices that gave rise to mass incarceration were not only backlash to the Civil Rights Movement by White elites, as some have proposed, but something more insidious: "frontlash," where "losers in a conflict become the architects of a new program, manipulating the issue space and altering the dimension of the conflict in an effort to regain their command of the agenda" (p 236). Michelle Alexander (2010) uses the lens of racial control to analyze the War on Drugs, with mass incarceration functioning to uphold a racial caste system. Similarly, Naomi Murakawa (2014) emphasizes the ideology of "racial liberalism" espoused by White liberals in the postwar period, describing how it gave rise to a racialized law-and-order agenda and the carceral state. However, the picture painted by Weaver, Alexander, and Murakawa has not been uncritically accepted. Forman (2017) and Michael Javen Fortner (2015) each highlight how African Americans contributed to mass incarceration, particularly members of the Black middle class. John Pfaff (2015) writes about a shift in prosecutor behavior in the early 1990s, revealing a new kind of punitiveness "inspired in no small part by a desire to use the criminal justice system (perhaps poorly) to try to rectify structural problems in relatively high-crime communities" (p. 177). Elizabeth Hinton's (2016) analysis complements Pfaff's in certain respects: she discusses how the War on Crime that began in the 1960s was a deeply misguided effort to address poverty-related problems faced by economically struggling Black communities. However, the concept of a racial institutional order does not require explicit White supremacist/antitransformative intent-or conversely, egalitarian transformative intent-but rather describes the "pressures to alter or to maintain the nation's racial ordering" operating at a subterranean level (King and Smith, 2005, p. 84). To deny that racial institutional orders matter to the U.S. imprisonment and policing regime is to deny that race matters. This, few would deny.

This brings us to regime change in the Global North. Here, as Fionnuala Ní Aoláin and Colm Campbell (2005) argue, the idea of sweeping political change often meets stubborn resistance: "Whereas nondemocratic societies may be faced with demands for institutional transformation, in democratic societies the imperative is typically to reform rather than to transform" (p. 187). A strong presumption that Global North countries "do not commit systematic violations of human rights" is operative, based on the notion that "once the initial breach is discovered, [a country's] own internal human rights protections should provide correctives and prevent reoccurrence" (Ní Aoláin and Campbell, 2005, p. 207). But systematic violations of human rights do occur, thus "the language of reform alone may not be sufficient to deliver the institutional and structural changes demanded by the transitional process" (Ní Aoláin and Campbell, 2005, p. 187). Hence the utility of the language of regime change in the Global North context: There is a built-in contrast with reformist efforts that preserve the status quo. What would it mean for the United States to undergo a regime change, then? In our view, if an egalitarian transformative racial institutional order came to dominate over its White supremacist/antitransformative counterpart, and was the fundamental determinant of what punishment and policing looked like in the United States, this would amount to a genuine transition.

This way of thinking about transitional justice in the United States has a connection with abolition democracy. In present-day activist circles, abolition democracy "calls for a constellation of democratic institutions and practices to displace policing and imprisonment while working to realize more equitable and fair conditions of collective life" (McLeod 2018, p. 1618). The term was originally coined by Du Bois ([1935]1998) to 
describe a Reconstruction-era ethos that didn't see ending slavery as sufficient, but was "convinced that [abolition] could be thoroughly accomplished only if the emancipated Negroes became free citizens and voters" incorporated "into the body civil, politic, and social, of the United States" (Du Bois [1935]1998, pp. 184, 189). ${ }^{5}$ Davis (2005) argues for the relevance of abolition democracy to contemporary abolitionist projects. "[I]t is not only, or not even primarily, about abolition as a negative process of tearing down, but it is also about building up, about creating new institutions," she writes (p. 73). We cannot abolish prisons "by wielding axes and literally hacking at prison walls" but must demand "new democratic institutions that take up the issues that can never be addressed by prisons in productive ways" (Davis 2005, p. 76). In her essay, "Constructing a Criminal Justice System Free of Racial Bias: An Abolitionist Framework," Roberts (2007) takes a similar stance. She proposes various measures aimed at dismantling the system of mass incarceration, from halting the construction of new prisons to outlawing the death penalty. "Abolishing these institutions should be accompanied by a redirection of criminal justice spending to rebuild the neighborhoods that they have devastated," she goes on to write. "There should be a massive infusion of resources to poor and low-income neighborhoods to help residents build local institutions, support social networks, and create social citizenship" (p. 285).

We see abolition democracy as providing a vision of the kind of regime change to which a country like the United States should aspire. It preserves transitional justice's longstanding idea of democracy and democratization as aims, and is directly concerned with how U.S. practices of imprisonment and policing undermine democratic citizenship, all while being wary of reformist projects that fail to challenge punishment as society's default response to interpersonal and state violence.

Abolition democracy moreover presents a cohesive vision of how a transition away from the U.S. imprisonment and policing regime and the transitional justice measures of truth and reparation fit together. Allegra M. McLeod (2018) discusses the contemporary abolitionist movement's on-the-ground experimentation with alternatives to punishment-focused responses to violence. One example is the movement for reparations as a response to the Chicago police department's use of torture, where the focus was on truth-telling and the victims' needs rather than locking up the officers who had sent many innocent Black people to jail. She quotes activist Mariame Kaba:

[T] he reparations ordinance... [is] an abolitionist document... [b]ecause it's a document that did not rely on the court, prison, and punishment system, to try to envision a more expansive view of justice. So while financial restitution was a part of that package, it also did a whole bunch of other things... [in terms of] rethinking justice for people who have been wronged, survivors of violence... Chicago is the first municipality in history to ever pass a reparations bill for law enforcement violence. So that's something that other cities are looking at for themselves now, as avenues for justice that are not personal and individual indictments of the police, not calls for cops to be jailed... (McLeod 2018, p. 1628).

This brings us to a related and final point about how abolition democracy and transitional justice - at least on some understandings - fit together. There is a large debate within the transitional justice literature about the extent to which there should be a focus on criminally prosecuting the individual perpetrators of human rights abuses (e.g., Fletcher and Weinstein, 2002; Leebaw 2011; Méndez 2001; Orentlicher 1991), whether restorative justice and other "therapeutic" methods of accountability wrong victims by letting torturers and other evildoers off the hook (e.g., Moghalu 2004; Wilson 2001; cf. Ame and 
Alidu, 2010), whether low-level participants in violence should receive amnesty (e.g., Malamud-Goti 1990; Mallinder 2014), whether "individualizing” wrongdoing via criminal trials misrepresents the systemic and collective nature of mass violence (Fletcher and Weinstein, 2002; Leebaw 2011), and so on. Abolition democracy takes a firm stand on the issues in this debate, siding with those who advocate pursuing alternatives to criminal punishment, affirming the moral worth of victims through repair rather than retribution, and thinking about violence systematically rather than in individualistic terms. In the context of the present-day United States, these dynamics were on display when Derek Chauvin, the police officer who murdered George Floyd, was found guilty. Journalist Moya Lothian McLean (2021) comments on the novelty of mainstream Democrats calling the criminal conviction "accountability" not "justice" - since justice would require sweeping structural changes aimed at overhauling a sociopolitical system where Black people face endemic, multifaceted violence.

Four years ago, perhaps, Chauvin's conviction would have led to widespread raucous celebration and numerous politicians declaring that 'justice has been served'... But we are battered and wiser. It's not just the abolitionists with decades in the trenches who now recognize that the criminal justice system and imprisonment are not synonymous with 'justice'-not when those same institutions are responsible for trapping the George Floyds of this world in deadly carceral cycles of criminalization in the first place (McLean 2021).

A similar observation can be made about reparations. Suppose that H.R. 40 became law and reparations proposals formulated by an H.R. 40 commission were enacted. This would provide accountability for the federal government's role as a perpetrator and collaborator in centuries of race-based violence against Black Americans. But unless accompanied by a regime change aimed at disrupting the deadly carceral cycles of criminalization and antiBlackness, this would not be justice.

\section{Conclusion}

An April 2021 report by the International Center for Transitional Justice The Color of Fustice: Transitional fustice and the Legacy of Slavery and Racism in the United States (Ladisch and Roccatello, 2021), cautions against dismissing the United States as a country to which transitional justice is applicable. "A common misconception is that transitional justice can only be applied in a society that is undergoing a significant transition, either at the end of a conflict or during a transfer of power," the authors of the report write. "However, while such a transition does facilitate efforts to reform institutions and redress past atrocities, what is needed are a political, social, and cultural opening and a public demand for change" (Ladisch and Roccatello, 2021, p. 2).

Many authors who advocate using the tools of transitional justice to reckon with statesponsored racial violence and human rights abuses in the United States and other Global North countries aim to persuade those who feel that no such reckoning is needed. They are skeptical of a sharp "emerging" democracy-"established" democracy distinction that too often functions to obfuscate or deny race-based injustice and structural inequalities. But in emphasizing that transitional justice is not only for contexts commonly viewed as transitional, the point often gets lost that justice requires a transition. ${ }^{6}$ As we have argued, the United States is not currently in a transitional moment with regard to its imprisonment and policing regime - the racial justice protests of 2020 notwithstanding, a genuine transformation away from this regime is not yet underway. "It is time," as Dorothy Roberts (2007) 
wrote, "for a third Reconstruction ushered in by a movement that cracks the racial order reinforced by the mass imprisonment of African Americans" (p. 272).

Acknowledgements. The authors thank Colleen Murphy for her comments on an earlier version of the article, as well as the anonymous reviewers for $D u$ Bois Review.

\section{Notes}

1 Authors like Thomas Obel Hansen (2011), Stephen Winter (2014), Dustin Sharp (2015), as well as Harry Hobbs (2016) argue against making the formal regime change context an essential part of the definition of transitional justice.

2 See also Mihai (2016): "Democratic shifts are generally seen to cover changes exemplified, at one end of the spectrum, by such phenomena as the rights revolution in the United States and, at the other, by the more profound transformations of societies coming out of major conflict and oppression" (p. 36). On this formulation, the United States has had transitional moments-the rights revolution, and of course, the end of enslavement and the Civil War, which is more paradigmatically a post-conflict transition-but is not currently a transitional society.

3 Collateral consequences can also result from the sheer fact of a criminal conviction, even if one does not serve prison time.

4 This is not to say that the context of a formal regime change is any guarantee that the tools of transitional justice will not be used superficially. Susan Harris Rimmer (2010) argues that East Timor's transitional justice efforts were inadequate in important respects, particularly concerning female victims of rape, forced marriage, and military sex slavery.

5 Abolition democracy's downfall was, according to Du Bois, an eventual anti-democratic alliance with business interests: "Thus a movement, which began primarily and sincerely to abolish slavery and insure the Negroes' rights, became coupled with a struggle of capitalism to retain control of the government as against Northern labor and Southern and Western agriculture" (Du Bois [1935]1998, p. 214).

6 This criticism is by no means aimed at the ICTJ report referenced: Virginie Ladisch and Anna Myriam Roccatello (2021) point out a number of formal measures that could be undertaken to significantly reduce imprisonment and policing-related violence.

\section{References}

Aiyetoro, Adjoa A. (2011). Why Reparations to African Descendants in the United States Are Essential to Democracy. Fournal of Gender, Race, and fustice, 14: 633-664.

Alexander, Michelle (2010). The New Fim Crow: Mass Incarceration in the Age of Colorblindness. New York: The New Press.

Ame, Robert K., and Seidu M. Alidu (2010). Truth and Reconciliation Commissions, Restorative Justice, Peacemaking Criminology, and Development. Criminal fustice Studies, 23(3): 253-268.

American Civil Liberties Union of Eastern Mississippi (2009). Suffering in Silence: Human Rights Abuses in St. Louis Correctional Centers. https://www.aclu-mo.org/sites/default/files/field_documents/aclusufferingful lreport.pdf (accessed September 1, 2021).

Anderson, Carol (2018). One Person, No Vote: How Voter Suppression Is Destroying Our Democracy. New York: Bloomsbury Publishing USA.

Arthur, Paige (2009). How Transitions Reshaped Human Rights: A Conceptual History of Transitional Justice. Human Rights Quarterly, 31: 321-367.

Auweraert, Peter Van der (2012). Ending the 2006 Internal Displacement Crisis in Timor-Leste: Between Humanitarian Aid and Transitional Justice. Geneva: International Organization for Migration. https://pub lications.iom.int/system/files/pdf/mrs44_13june2012.pdf (accessed September 1, 2021).

Bagaric, Mirko, Sandeep Gopalan, and Marissa R. Florio (2017). A Principled Strategy for Addressing the Incarceration Crisis: Redefining Excessive Imprisonment as a Human Rights Abuse. Cardozo Law Review, 38 (5): 1663-1725.

Baumgartner, Frank, Derek Epp, and Kelsey Shoub (2018). Suspect Citizens: What 20 Million Traffic Stops Tell Us About Policing and Race. New York: Cambridge University Press.

Bell, Monica C. (2017). Police Reform and the Dismantling of Legal Estrangement. The Yale Law Fournal, 126: 2054-2150. 
Berry, Mary Frances (2005). My Face Is Black Is True: Callie House and the Struggle for Ex-Slave Reparations. New York: Alfred A. Knopf.

Bobo, Lawrence D., and James R. Kluegel (1997). Status, Ideology, and Dimensions of Whites' Racial Beliefs and Attitudes: Progress and Stagnation. In Steven A. Tuch and Jack K. Martin (Eds.), Racial Attitudes in the 1990s: Continuity and Change, pp. 93-120. Westport, CT: Praeger.

Bobo, Lawrence D., and Victor Thompson (2010). Racialized Mass Incarceration: Poverty, Prejudice, and Punishment. In Hazel R. Markus and Paula Moya (Eds.), Doing Race: 21 Essays for the 21st Century, pp. 322-355. New York: W. W. Norton \& Company.

Boxill, Bernard R. (2003). A Lockean Argument for Black Reparations. Fournal of Ethics, 7(1): 63-91.

Brito, Alexandra Barahona de, Carmen González-Enríquez, and Paloma Aguilar (2001). Introduction. In Alexandra Barahona de Brito and Carmen González-Enríquez (Eds.), The Politics of Memory: Transitional Justice in Democratizing Societies, pp. 1-39. Oxford, UK: Oxford University Press.

Butler, Paul (2016). The System Is Working the Way It Is Supposed To: The Limits of Criminal Justice Reform. Georgetown Law Journal, 104: 1419-1478.

Butler, Paul (2017). Chokehold: Policing Black Men. New York: The New Press.

Carbado, Devon W. (2017). From Stop and Frisk to Shoot and Kill: Terry v. Obio's Pathway to Police Violence. UCLA Law Review, 64: 1508-1552.

Carpenter, Dick M., II, Lisa Knepper, Angela C. Erickson, and Jennifer McDonald (2015). Policing for Profit: The Abuse of Civil Asset Forfeiture, Second Edition. Arlington, VA: Institute for Justice. https://ij.org/wpcontent/uploads/2015/11/policing-for-profit-2nd-edition.pdf (accessed September 1, 2021).

Chettiar, Inimai, and Michael Waldman (Eds.) (2015). Solutions: American Leaders Speak Out on Criminal fustice. New York: Brennan Center for Justice.

Chetty, Raj, Nathaniel Hendren, Maggie R. Jones, and Sonya R. Porter (2020). Race and Economic Opportunity in the United States: An Intergenerational Perspective. The Quarterly fournal of Economics, 135(2): 711-783.

Clear, Todd R. (2021). Decarceration Problems and Prospects. Annual Review of Criminology, 4(1): 239-260.

Congress.gov (2021a). S.40 - 117th Congress (2021-2022): Commission to Study and Develop Reparation Proposals for African Americans Act. January 25. https://www.congress.gov/bill/117th-congress/senate-bill/40 (accessed September 1, 2021).

Congress.gov (2021b). H.R.40 - 117th Congress (2021-2022): Commission to Study and Develop Reparation Proposals for African Americans Act. April 14. https://www.congress.gov/bill/117th-congress/house-bill/40 (accessed September 1, 2021).

Congress.gov (2021c). S.Con.Res.6 - 117th Congress (2021-2022): A Concurrent Resolution Urging the Establishment of a United States Commission on Truth, Racial Healing, and Transformation. February 25. https://www.congress.gov/bill/117th-congress/senate-concurrent-resolution/6 (accessed September 1, 2021).

Congress.gov (2021d). H.Con.Res.19 - 117th Congress (2021-2022): Urging the establishment of a United States Commission on Truth, Racial Healing, and Transformation. April 28. https://www.congress.gov/bill/117thcongress/house-concurrent-resolution/19 (accessed September 1, 2021).

Coulthard, Glen Sean (2014). Red Skin, White Masks: Rejecting the Colonial Politics of Recognition. Minneapolis, MN: University of Minnesota Press.

Davidovic, Jovana (2012). Timor-Leste and Transitional Justice: Should We Pursue International Prosecutions for the Crimes Committed in East Timor in 1999? In Larry May and Andrew Forcehimes (Eds.), Morality, fus Post Bellum, and International Law, pp. 78-112. Cambridge, UK: Cambridge University Press.

Davis, Angela Y. (2005). Abolition Democracy: Beyond Empire, Prisons, and Torture. New York: Seven Stories Press.

Dawson, Michael C., and Rovana Popoff (2004). Reparations: Justice and Greed in Black and White. Du Bois Review: Social Science Research on Race, 1(1): 47-91.

Department of Justice (DOJ) (2015). Investigation of the Ferguson Police Department Washington DC: United States Department of Justice Civil Rights Division.

Department of Justice (2019). Investigation of Alabama's State Prisons for Men https://www.justice.gov/opa/ press-release/file/1150276/download (accessed September 2, 2021).

Du Bois, W. E. B. ([1935]1998). Black Reconstruction in America, 1860-1880. New York: The Free Press.

Edwards, Frank, Hedwig Lee, and Michael Esposito (2019). Risk of Being Killed by Police Use of Force in the United States by Age, Race-Ethnicity, and Sex. Proceedings of the National Academy of Sciences, 116(34): $16793-16798$.

Elinson, Zusha, Dan Frosch, and Joshua Jamerson (2021). Cities Reverse Defunding the Police Amid Rising Crime. The Wall Street Fournal, May 26. https://www.wsj.com/articles/cities-reverse-defunding-the-policeamid-rising-crime-11622066307 (accessed September 2, 2021). 
Enns, Peter K. (2016). Incarceration Nation: How the United States Became the Most Punitive Democracy in the World. Cambridge, UK: Cambridge University Press.

Epp, Charles R., Steven Maynard-Moody, and Donald Haider-Markel (2014). Pulled Over: How Police Stops Define Race and Citizenship. Chicago, IL: University of Chicago Press.

Epperson, Matthew, and Carrie Pettus-Davis (2017). Smart Decarceration: Achieving Criminal fustice Transformation in the 21st Century. Oxford, UK: Oxford University Press.

Evans, Christine (2012). Case Study: Reparations in East Timor. In The Right to Reparation in International Law for Victims of Armed Conflict, pp. 185-202. Cambridge Studies in International and Comparative Law. Cambridge, UK: Cambridge University Press.

Fenton, Justin (2021). We Own This City: A True Story of Crime, Cops, and Corruption. New York: Penguin Random House.

Fernandes, Clinton (2010). East Timor and the Struggle for Independence. In Lilian A. Barria and Steven D. Roper (Eds.), The Development of Institutions of Human Rights, pp. 163-178. London: Palgrave Macmillan.

Fisher, Max (2021). Indigenous People Advance a Big Goal: Reversing Colonialism. The New York Times, June 19. https://www.nytimes.com/2021/06/17/world/canada/indigenous-kamloops-graves.html (accessed September 2, 2021).

Flanigan, Jessica, and Christopher Freiman (2020). Drug War Reparations. Res Philosophica, 97(2): 141-168.

Fletcher, Laurel E., and Harvey M. Weinstein (2002). Violence and Social Repair: Rethinking the Contribution of Justice to Reconciliation. Human Rights Quarterly, 24(3): 573-639.

Forman, James, Jr. (2017). Locking Up Our Own: Crime and Punishment in Black America. New York: Farrar, Straus, and Giroux.

Fortner, Michael Javen (2015). Black Silent Majority: The Rockefeller Drug Laws and the Politics of Punishment. Cambridge, MA: Harvard University Press.

Futterman, Craig B., Chaclyn Hunt, and Jamie Kalven (2016). Youth/Police Encounters on Chicago's South Side: Acknowledging the Realities. University of Chicago Legal Forum, 2016 (Article 5): 125-211.

Garland, David (Ed.) (2001). Mass Imprisonment: Social Causes and Consequences. London: SAGE Publications.

Ghandnoosh, Nazgol (2020). U.S. Prison Decline: Insufficient to Undo Mass Incarceration. The Sentencing Project, May 19. https://www.sentencingproject.org/publications/u-s-prison-decline-insufficient-undo-massincarceration/ (accessed September 2, 2021).

Gilmore, Ruth Wilson (2015). The Worrying State of the Anti-Prison Movement. Social fustice Blog, February 23. https://www.prisonlegalnews.org/news/2015/mar/2/worrying-state-anti-prison-movement/ (accessed September 2, 2021).

Goldstein, Rebecca, Michael W. Sances, and Hye Young You (2020). Exploitative Revenues, Law Enforcement, and the Quality of Government Service. Urban Affairs Review, 56(1): 5-31.

Goode, Erica (2013). U.S. Prison Populations Decline, Reflecting New Approach to Crime. The New York Times, July 25. https://www.nytimes.com/2013/07/26/us/us-prison-populations-decline-reflecting-new-approachto-crime.html (accessed September 2, 2021).

Graham v. Connor (1989). 490 U.S. 386.

Gramlich, John (2020). How Border Apprehensions, ICE Arrests and Deportations Have Changed under Trump. Pew Research Center, March 2. https://www.pewresearch.org/fact-tank/2020/03/02/how-borderapprehensions-ice-arrests-and-deportations-have-changed-under-trump/ (accessed September 2, 2021).

Gray, David C. (2010). Extraordinary Justice. Alabama Law Review, 62(1): 55-109.

Haltiwanger, John, and Walt Hickey (2019). 2020 Democrats Have Started to Clash Over Slavery Reparations, But A New Poll Shows Most Liberals Support the Idea. Business Insider, March 13. https://www.businessinsi der.com/majority-of-liberals-support-slavery-reparations-insider-poll-shows-2019-3 (accessed September 2, 2021).

Hansen, Thomas Obel (2011). Transitional Justice: Toward a Differentiated Theory. Oregon Review of International Law, 13(1): 1-46.

Heaton, Paul, Sandra Mayson, and Megan Stevenson (2017). The Downstream Consequences of Misdemeanor Pretrial Detention. Stanford Law Review, 69(3): 711-794.

Hinton, Elizabeth (2016). From the War on Poverty to the War on Crime: The Making of Mass Incarceration in America. Cambridge, MA: Harvard University Press.

Hobbes, Thomas ([1651]1994). Leviathan. Edited by Edwin Curley. Indianapolis, IN: Hackett Publishing.

Hobbs, Harry (2016). Locating the Logic of Transitional Justice in Liberal Democracies: Native Title in Australia. University of New South Wales Law fournal, 39(2): 512-552.

Human Rights Watch (1998). Shielded from fustice: Police Brutality and Accountability in the United States. New York: Human Rights Watch.

Illinois v. Wardlow (2000). 528 U.S. 119. 
Institute for Justice (2016). Update: U.S. Agrees to Drop Forfeiture Case and Return All of Charles Clarke's Money Plus Interest. Press Release, November 29. https://ij.org/press-release/update-u-s-agrees-drop-forfei ture-case-return-charles-clarkes-money-plus-interest/ (accessed September 2, 2021).

Jackman, Mary R., and Kimberlee A. Shauman (2019). The Toll of Inequality: Excess African American Deaths in the U.S. over the Twentieth Century. Du Bois Review: Social Science Research on Race, 16(2): 291-340.

Jenkins, Austin (2021). With 12 New Laws, Washington State Joins Movement to Overhaul Policing. National Public Radio, May 18. https://www.npr.org/2021/05/18/997974519/a-dozen-police-reform-bills-signedinto-law-in-washington-state (accessed October 21, 2021).

Fohnson v. Glick (1973). 481 F.2. ${ }^{\text {nd }} .1028$.

King, Desmond S., and Jennifer M. Page (2018). Towards Transitional Justice?: Black Reparations and the End of Mass Incarceration. Ethnic and Racial Studies, 41(4): 739-758.

King, Desmond S., and Rogers M. Smith (2005). Racial Orders in American Political Development. American Political Science Review, 99(1): 75-92.

Kritz, Neil J. (Ed.) (1995). Transitional fustice: How Emerging Democracies Reckon with Former Regimes. Washington, DC: United States Institute of Peace Press.

Ladisch, Virginie, and Anna Myriam Roccatello (2021). The Color of Justice: Transitional Justice and the Legacy of Slavery and Racism in the United States. International Center for Transitional Justice. https://www.icti.org/ publication/color-justice-transitional-justice-and-legacy-slavery-and-racism-united-states (accessed September 2, 2021).

Lee, Hedwig, Tyler McCormick, Margaret T. Hicken, and Christopher Wildeman (2015). Racial Inequalities in Connectedness to Imprisoned Individuals in the United States. Du Bois Review: Social Science Research on Race, 12 (2): 269-282.

Leebaw, Bronwyn (2011). fudging State-Sponsored Violence, Imagining Political Change. Cambridge, UK: Cambridge University Press.

MacFarquhar, Neil (2020). Many Claim Extremists Are Sparking Protest Violence. But Which Extremists? The New York Times, May 31. https://www.nytimes.com/2020/05/31/us/george-floyd-protests-white-suprem acists-antifa.html (accessed September 2, 2021).

MacLachlan, Alice, and Allen Speight (Eds.) (2013). Fustice, Responsibility, and Reconciliation in the Wake of Conflict. Dordrecht, Netherlands: Springer.

Malamud-Goti, Jaime (1990). Transitional Governments in the Breach: Why Punish State Criminals? Human Rights Quarterly, 12(1): 1-16.

Mallinder, Louise (2014). Amnesties in the Pursuit of Reconciliation, Peacebuilding, and Restorative Justice. In Jennifer J. Llewellyn and Daniel Philpott (Eds.), Restorative fustice, Reconciliation, and Peacebuilding, pp. 138-173. Oxford, UK: Oxford University Press.

Martin, William G., and Joshua M. Price (Eds.) (2016). After Prisons?: Freedom, Decarceration, and fustice Disinvestment. Lanham, MD: Lexington Books.

McLean, Moya Lothian (2021). Derek Chauvin's Conviction Has Left Us Hollow Because the Bare Minimum Is No Longer Enough. Gal-Dem, April 21. https://gal-dem.com/derek-chauvin-george-floyd/ (accessed September 2, 2021).

McLeod, Allegra M. (2018). Envisioning Abolition Democracy. Harvard Law Review, 132: 1613-1649.

Méndez, Juan E. (2001). National Reconciliation, Transnational Justice, and the International Criminal Court. Ethics \& International Affairs, 15(1): 25-44.

Mihai, Mihaela (2016). Negative Emotions and Transitional fustice. New York: Columbia University Press.

Mihr, Anja (2021). An Introduction to Transitional Justice. In Olivera Simi区 (Ed.), An Introduction to Transitional Fustice, 2nd ed., pp. 1-28. Abingdon, UK: Routledge.

Moghalu, Kingsley Chiedu (2004). Reconciling Fractured Societies: An African Perspective on the Role of Judicial Prosecutions. In Ramesh Thakur and Peter Malcontent (Eds.), From Sovereign Impunity to International Accountability: The Search for fustice in a World of States, pp. 197-223. Tokyo, Japan: United Nations University Press.

Murakawa, Naomi (2008). The Origins of the Carceral Crisis: Racial Order as 'Law and Order' in Postwar American Politics. In Joseph E. Lowndes, Julie Novkov, and Dorian T. Warren (Eds.), Race and American Political Development, pp. 234-255. New York: Routledge.

Murakawa, Naomi (2014). The First Civil Right: How Liberals Built Prison America. Oxford, UK: Oxford University Press.

Murphy, Colleen (2017). The Conceptual Foundations of Transitional fustice. Cambridge, UK: Cambridge University Press.

Nagy, Rosemary (2008). Transitional Justice as Global Project: Critical Reflections. Third World Quarterly, 29(2): 275-289. 
Natapoff, Alexandra (2018). Punishment without Crime: How Our Massive Misdemeanor System Traps the Innocent and Makes America More Unequal. New York: Basic Books.

Nevius, Marcus P. (2021). The Legacy of Racial Hatred in the January 6 Insurrection. FSTOR Daily, February 24. https://daily.jstor.org/the-legacy-of-racial-hatred-in-the-january-6-insurrection/ (accessed September 2, 2021).

Newman, Zachary, and Osagie K. Obasogie (2018). The Futile Fourth Amendment: Understanding Police Excessive Force Doctrine Through an Empirical Assessment of Graham v. Connor. Nortbwestern University Law Review, 112(6): 1465-1500.

Ní Aoláin, Fionnuala, and Colm Campbell (2005). The Paradox of Transition in Conflicted Democracies. Human Rights Quarterly, 27(1): 172-213.

Nicholson-Crotty, Sean, Jill Nicholson-Crotty, Danyao Li, and Siân Mughan (2021). Race, Representation, and Assets Forfeiture. International Public Management Journa,1 24(1): 47-66.

O'Brien, Brendan, and Joseph Ax (2021). Chicago Suburb's Plan to Pay Black Residents Reparations Could Be a National Model. Reuters, March 22. https://www.reuters.com/article/us-usa-race-reparationsidUSKBN2BD0B8 (accessed September 2, 2021).

Obasogie, Osagie K. (2020). More Than Bias: How Law Produces Police Violence. Boston University Law Review, 100: 771-785.

Obasogie, Osagie K., and Zachary Newman (2019). The Endogenous Fourth Amendment: An Empirical Assessment of How Police Understandings of Excessive Force Become Constitutional Law. Cornell Law Review, 104(5): 1281-1335.

Oliver, Melvin, and Thomas Shapiro (2006). Black Wealth/White Wealth: A New Perspective on Racial Inequality. 2nd ed. New York: Routledge.

Olsen, Henry (2021). We're Facing a Massive Spike in Violent Crime. Democrats Can't Take It Lightly. The Washington Post, February 11. https:/www.washingtonpost.com/opinions/2021/02/11/were-facing-massivespike-violent-crime-democrats-cant-take-it-lightly/ (accessed September 2, 2021).

Orentlicher, Diane F. (1991). Settling Accounts: The Duty to Prosecute Human Rights Violations of a Prior Regime. Yale Law Fournal, 100: 2537-2615.

Orfield, Gary, and Erica Frankenberg (2014). Brown at 60: Great Progress, a Long Retreat and an Uncertain Future. Civil Rights Project at UCLA. https://www.civilrightsproject.ucla.edu/research/k-12-education/inte gration-and-diversity/brown-at-60-great-progress-a-long-retreat-and-an-uncertain-future/Brown-at-60051814.pdf (accessed September 2, 2021).

Page, Jennifer M. (2019). Reparations for Police Killings. Perspectives on Politics, 17(4): 958-972.

Patterson, Evelyn J. (2017). The Strategies, Complexities, and Realities of Zero Prison Population Growth. Social Sciences, 6(2): 60.

Pfaff, John (2015). The War on Drugs and Prison Growth: Limited Importance, Limited Legislative Options. Harvard Fournal on Legislation, 52: 173-222.

Pfaff, John (2017). Locked In: The True Causes of Mass Incarceration and How to Achieve Real Reform. New York: Basic Books.

Rimmer, Susan Harris (2010). Gender and Transitional fustice: The Women of East Timor. New York: Routledge.

Roberts, Dorothy E. (2003). The Social and Moral Cost of Mass Incarceration in African American Communities. Stanford Law Review, 56: 1271-1305.

Roberts, Dorothy E. (2007). Constructing a Criminal Justice System Free of Racial Bias: An Abolitionist Framework. Columbia Human Rights Law Review, 39: 261-285.

Sances, Michael W., and Hye Young You (2017). Who Pays for Government?: Descriptive Representation and Exploitative Revenue Sources. The Fournal of Politics, 79(3): 1090-1094.

Sawyer, Wendy (2019). How Race Impacts Who Is Detained Pretrial. Prison Policy Initiative, October 9. https:// www.prisonpolicy.org/blog/2019/10/09/pretrial_race/ (accessed September 2, 2021).

Schwirtz, Michael, and Michael Winerip (2015). Kalief Browder, Held at Rikers Island for 3 Years Without Trial, Commits Suicide.” The New York Times, June 8. https://www.nytimes.com/2015/06/09/nyregion/kalief-brow der-held-at-rikers-island-for-3-years-without-trial-commits-suicide.html (accessed September 2, 2021).

Sharp, Dustin N. (2015). Emancipating Transitional Justice from the Bonds of the Paradigmatic Transition. International fournal of Transitional fustice, 9(1): 150-169.

Shelby, Tommie (2016). Dark Ghettos: Injustice, Dissent, and Reform. Cambridge, MA: Belknap Press.

Singla, Akheil, Charlotte Kirschner, and Samuel B. Stone (2020). Race, Representation, and Revenue: Reliance on Fines and Forfeitures in City Governments. Urban Affairs Review, 56(4): 1132-1167.

Smith, Rogers M., and Desmond King (2021). White Protectionism in America. Perspectives on Politics, 19(2): $460-478$. 
Sobey, Rick (2020). George Floyd Protests in Boston: 'This Time Is Different.' Boston Herald, June 4. https:// www.bostonherald.com/2020/06/03/george-floyd-protests-in-boston-this-time-is-different/ (accessed September 2, 2021).

Stevenson, Bryan (2017). The Presumption of Guilt: The Legacy of America's History of Racial Injustice. In Angela J. Davis (Ed.), Policing the Black Man: Arrest, Prosecution, and Imprisonment, pp. 3-30. New York: Pantheon Books.

Tai, Stephanie (2016). China's Two-Child Policy: An Assault on Human Rights. Oxford Human Rights Hub, January 19. https://ohrh.law.ox.ac.uk/the-two-child-policy-an-assault-on-human-rights/ (accessed September 2, 2021).

Taylor, G. Flint (2016). The Long Path to Reparations for the Survivors of Chicago Police Torture. Northwestern Journal of Law and Social Policy, 11: 330-353.

Teitel, Ruti G. (2014). Globalizing Transitional fustice. Oxford, UK: Oxford University Press.

Travis, Jeremy (2002). Invisible Punishment: An Instrument of Social Exclusion. In Marc Mauer and Meda Chesney-Lind (Eds.), Invisible Punishment: The Collateral Consequences of Mass Imprisonment, pp. 15-36. New York: The New Press.

Travis, Jeremy, Bruce Western, and Steve Redburn (2014). The Growth of Incarceration in the United States: Exploring Causes and Consequences. Washington DC: National Academies Press.

Treisman, Rachel (2021). Kentucky Law Limits Use of No-knock Warrants, A Year After Breonna Taylor's Killing. National Public Radio, April 9. https://www.npr.org/2021/04/09/985804591/kentucky-law-limitsuse-of-no-knock-warrants-a-year-after-breonna-taylors-killin (accessed October 21, 2021).

United Nations Human Rights Council (UNHRC) (2016). Report of the Working Group of Experts on People of African Descent on Its Mission to the United States of America. https://digitallibrary.un.org/record/ 848570 ? In=en (accessed September 2, 2021).

Valls, Andrew (2003). Racial Justice as Transitional Justice. Polity, 36(1): 53-71.

Walter, Barbara F. (2015). Why Bad Governance Leads to Repeat Civil War. Fournal of Conflict Resolution, 59(7): 1242-1272.

Weaver, Vesla M. (2007). Frontlash: Race and the Development of Punitive Crime Policy. Studies in American Political Development, 21(2): 230-265.

Western, Bruce (2002). "The Impact of Incarceration on Wage Mobility and Inequality. American Sociological Review, 67: 526-546.

Williams, Juleyka Lantigua (2018). Three-Strikes Drug Policies Failed. It's Time for Reparations. Marshall Project, August 27. https://www.themarshallproject.org/2018/08/26/three-strikes-didn-t-work-it-s-time-topay-reparations (accessed September 2, 2021).

Wilson, Stuart (2001). The Myth of Restorative Justice: Truth, Reconciliation and the Ethics of Amnesty. South African fournal on Human Rights, 17(4): 531-562.

Wilson, Sarah (2021). DOJ's Proposed 2022 Budget for Grant Funding Reveals Focus on Police Reform. Police1. com, October 1. https://www.police1.com/police-grants/articles/dojs-proposed-2022-budget-for-grant-fund ing-reveals-focus-on-police-reform-xRjLiMGDvlMvBvyC/ (accessed October 21, 2021).

Winter, Stephen (2014). Transitional fustice in Established Democracies: A Political Theory. London: Palgrave Macmillan.

Jennifer Page is Assistant Professor in Political Theory at the University of Zurich. She has also been a Postdoctoral Researcher at the University of Zurich, the Ruth J. Simmons Postdoctoral Fellow at Brown University's Center for the Study of Slavery \& Justice, and a Visiting Lecturer at Institute d'Études Politiques de Paris (Sciences Po). She has published in journals such as Perspectives on Politics, Social Theory and Practice, and Ethnic and Racial Studies. She is currently completing a book on reparations.

Desmond King is the Andrew W. Mellon Professor of American Government at the University of Oxford, and a Fellow of the British Academy and American Academy of Arts and Sciences. His publications include Separate and Unequal: African Americans and the US Federal Government (2007), Still A House Divided: Race and Politics in Obama's America with Rogers M. Smith (2011), Making Americans: Immigration, Race and the Origins of the Diverse Society (2002), and The Liberty of Strangers: Making the American Nation (2005) as well as numerous articles. His op-eds have appeared in The New York Times and Financial Times.

Cite this article: Page, Jennifer M. and Desmond King (2022). Truth and Reparation for the U.S. Imprisonment and Policing Regime: A Transitional Justice Perspective. Du Bois Review: Social Science Research on Race, 19: 209-231. https://doi.org/10.1017/S1742058X21000357 